\title{
Operational and Intelligence Activities of the Law Enforcement Agencies in the System of Ensuring National Security
}

\author{
Alexander Ivanovich Melikhov ${ }^{*}$, Gennady Svyatoslavovich Pratsko ${ }^{2}$, Victoria \\ Aleksandrovna Chistova ${ }^{1}$, Olga Dmitrievna Tyutyunik ${ }^{1}$, and Olga Aleksandrovna \\ Nenakhova $^{1}$ \\ ${ }^{1}$ Volgograd Academy of the Ministry of Internal Affairs of Russia, Department of Constitutional and \\ Administrative Law, Volgograd, Russia \\ ${ }^{2}$ Don State Technical University, Faculty of Law, Department of Commercial and Business Law, \\ Rostov-on-Don, Russia
}

\begin{abstract}
The transition to the postmodern stage of development of Russian society, by the subsequent change of the system of civilizational values, required the scientific development of a new attitude to security as a basic human need with regard to changing the nature of traditional threats and interests and the emergence of completely new ones. The process of globalization being developed in the information age weakens traditional state institutions and requires a new look at national security not only as a category of foreign policy and military matters but also as an internal problem solved through operational and intelligence activities. The purpose of the study was to identify the current problems in the theory of national security by means of an analysis of scientific studies of the phenomenon of security in Russia; to consider security as a function and feature of the social system; to consider the Operational and intelligence activities of the law enforcement agencies as a mean for ensuring national security; to identify the conditions and factors of operational and intelligence activities that negatively affect the effectiveness of ensuring national security. In the course of the research, using computer indexing, about 1300 scientific, educational and methodological sources on national security and internal affairs issues have been processed and analyzed in the semantic, philosophical and legal aspects. The study examines modern theoretical and practical problems of ensuring national security as part of operational and intelligence activities of the law enforcement agencies. Operational and intelligence activities is considered in the national security system as a means of its information support, as well as as a tool for combating criminal, military and other threats. For the first time, considered are the conditions and factors of the operational and intelligence activities that negatively affect the effectiveness of ensuring national security.
\end{abstract}

*Corresponding author: M-13913@mail.ru 
Keywords: national security, human rights, operational and intelligence activities, private investigation

\section{Introduction}

The process of globalization being developed in the information age weakens traditional state institutions and requires a new look at national security not only as a category of foreign policy and military matters but also as an internal problem solved using operational and intelligence activities.

Over the past 20 years, there has been an active rulemaking in the sphere of security issues in federal legislation and legal doctrine, so the concept of national security has been changed by presidential decrees three times, 17 federal laws on various types of security have been adopted (according to the search results of the ConsultantPlus reference legal system). The adoption of a significant quantity of laws was preceded by a serious scientific development of the problems of legislation.

Modern Internet databases of the Russian State Library (www.rsl.ru), provide wide access to the national scientific heritage in the sphere of humanities from around the world, and due to the obligation to place the materials of the thesis without restrictive labels on the websites of the Higher Attestation Commission and the organization where the Thesis Board was established, which accepted the thesis for consideration in the information and telecommunications network of the Internet, established by the decree of the Government of the Russian Federation odd. f September 24, 2013, No. 842 "On the procedure for awarding Academic Degrees", the modern researcher can conduct the most comprehensive study of the history of the scientific problems developed, including on national security issues.

These allowed to fully disclose the problems of operational and intelligence activities of the law enforcement agencies in the system of ensuring national security.

\section{Methods}

In the study of the place of the operational and intelligence activities of the law enforcement agencies in the system of ensuring national security, the authors widely used the dialectical method of scientific knowledge (G. Hegel, K. Marx), which allowed considering any phenomenon or process not in statics, but in dynamics. This also allowed to find the interrelationships and contradictions of the considered processes and phenomena, to make suggestions on ways of further development of the state policy of ensuring national security using the operational and intelligence activities of the police. The use of the dialectical method also allowed to identify of important essential elements of legal relations in the field of ensuring national security, as well as factors that negatively affect their effectiveness, to reveal the interdependence of the range of entities providing law enforcement services with the level of national security. The article also extensively uses methods of social systems theory and management theory, as well as game theory, which allow considering the behavior of participants in security relations from the standpoint of economic expediency $[1,2]$.

\section{Discussion}

In this work, based on the analysis and systematization of humanitarian scientific developments, the consistent patterns of the study of security issues in Russia are revealed. The most wide security issues are considered in law, philosophy, sociology and political science. In law science, the greatest attention is paid to the study of the concept of "security" 
in scientific works on administrative law, the theory of state and law, and constitutional law. It widely covers the areas of development of security theory [3], foreign experience in ensuring security [4-6], different aspects of public [7], information [8], economic, military [9], state [10], environmental [11] and criminological security [12]. More than a third part of humanitarian scientific works are devoted to the study of the problems of ensuring "national security". However, the research performed within the framework of departmental science are traditionally more concerned with the problems of public safety, personal safety, the safety of participants in criminal proceedings, and ensuring the economic security of the Russian state. The activities of the law enforcement agencies in the system of ensuring "national security" are poorly studied.

Currently, the theory of national security faces such problems as: the lack of dialectical, systemic, functional, structural, concrete-historical approaches in research; the consideration of these phenomena as isolated from the theory of social systems and management theory; the lack of definition of the phenomenon of "security" and the unity of scientific opinions regarding the conceptual apparatus of the phenomena of "security", "security system", "national security" and determining the place of these phenomena in the state system; the exclusion of the scientific specialty "management theory" from the list of scientific specialties.

The current scope of research in the category of "national security" makes it relevant and appropriate to establish in the framework of legal sciences a new scientific specialty dedicated to the study of national security along with public administration [13]. Before the creation of such a specialty, it is advisable to develop certain legal and applied aspects of the scientific study of national security within the framework of a legal scientific specialty dedicated to one of the main tools for ensuring national security which is operational and intelligence activities.

\section{Conclusion}

When determining the place of the operational and intelligence activities in the hierarchy of types of social systems, it could be mentioned that the system of operational and intelligence activities is a subspecies of the state system and belongs to the group of systems of activities of state law enforcement agencies.

Based on the provisions of dialectics, social systems theory, and management theory, national security and operational and intelligence activities shall be considered as social systems. According to the National Security Strategy of the Russian Federation, the national security system includes a set of state authorities and local self-government bodies implementing state policy in the field of national security and the tools they have, the system of operational and intelligence activities includes a set of operational divisions of state agencies authorized to do so by Federal Law No. 144-FZ dd. of 12.08.1995 "On Operational and intelligence activities" (hereinafter - the Federal Law "On operational and intelligence activities").

In turn, the operational and intelligence activities is a subsystem formation of the national security system that provides its information support due to the fact that according to Article 2 of the Federal Law "On operational and intelligence activities", the task of the operational and intelligence activities is to obtain information about events or actions (inaction) that pose a threat to the state, military, economic, information or environmental security of the Russian Federation), while the operational and intelligence activities and national security simultaneously remain independent types of social systems. The totality of all agencies that perform operational and intelligence activities represents a system of operational and intelligence activities, and the totality of agencies of the system of operational and intelligence activities that perform the extraction of information about events or actions 
(inaction) that pose a threat to the state, military, economic, information or environmental security of the Russian Federation represents a system of information support for the national security system.

When considering the role and significance of the criminal process and the operational and intelligence activities in the system of ensuring national security from criminal threats, it has been found that the criminal process and the operational and intelligence activities are not only independent tools for ensuring national security, but also contain a universal procedure for access to state enforcement measures for authorized entities of the national security system.

The main purpose of the criminal process is to ensure justice as a national value and a constitutional value when applying criminal responsibility and criminal procedural measures of coercion in the fight against criminal threats that have taken the form of crimes.

The operational and intelligence activities cover a larger range of tasks, objects and threats to national security than the criminal process. From the position of security theory, the main purpose of the operational and intelligence activities is not to establish justice or search for the truth, but to directly ensure the security of a person, society and the state from criminal threats. In contrast to the criminal process, the operational and intelligence activities provide an opportunity to identify, prevent, neutralize, suppress and destroy all types of criminal threats not only at the stage of criminal prosecution, but also at the stages of the emergence of intent, preparation for a crime that is not covered by criminal legislation; to combat criminal actions that have not taken the form of crimes; to repel threats generated by events, artificial intelligence, unconscious or (and) innocent activity, accidental coincidence; to counteract criminal threats for undisclosed, staged and disguised crimes whose criminal proceeding have been suspended or terminated.

In the theory of criminal procedure, the role of the operational and intelligence activities is providing, while in the theory of national security, the transition of the fight against criminal threats to the criminal procedure form is one of many possible scenarios for the development of the operational and intelligence activities, which puts it in the first place in ensuring national security.

The authors propose a number of amendments and additions to the domestic legislation on operational and intelligence activities of the police, which allow minimizing the number of human rights violations during operational and intelligence activities [14].

The application of operational and intelligence activities for achieving economic and political goals, rather than for combating criminal and other threats and providing information for national security, leads to the commercialization of state law enforcement activities and, as a result, the monopolization of the market for security and justice services [15]. Currently, law enforcement officers, due to the lack of a system of regulatory motivation and in order to save departmental resources, do not take the initiative in identifying, disclosing and investigating crimes in the field of relations between private economic entities, while at the same time providing services of ensuring their real security and protect their interests on a conspiratorial and illegal commercial basis. These circumstances have led to the monopolization of the market for security services by law enforcement agencies, which contributes to their illegal enrichment and moral corruption, the preservation of a significant share of the shadow economy and conditions for corruption and criminalization of economic and financial relations, which ultimately makes the Russian jurisdiction unattractive for doing business and investing.

The study was made with no third-party financial support. 


\section{References}

1. M. Dewatripont and J. Tirole, J. Polit. Ec. 107(1), 1-39 (1999)

2. K. Nakao and M. Tsumagari, Law \& Ec. 8(1), 137-159 (2012)

3. E.A. Matvienko, et al. Osnovy teorii natsional'noi bezopasnosti [Fundamentals of the theory of national security] (Volgograd, 2017)

4. V.P. Nazarov, Bul. MGIMO Univ. 2(13), 436-441 (2012)

5. Yu.V. Lutsenko, O.V. Kravchuk, Yu.V. Tsiganyuk, and S.V. Klimenko, Rus. J. Crim. 13(4), 680-690 (2019)

6. A.P. Anisimov, Bul. Saratov State Law Acad. 4(99), 182-187 (2014)

7. A.P. Alekseeva, Bul. Voronezh State Univ. Ser. Law. 12(5), 12-23 (2019)

8. M.A. Efremova, Bul. Perm Univ. Law Sc. 36, 222-230 (2017)

9. A.V. Bredikhin, Bul. Volgograd State Univ. Ser. 4: History. Reg. St. Int. Rel. 25(5), 234-243 (2020)

10. V.N. Voronin, Rus. J. Crim. 11(3), 569-576 (2017)

11. A.P. Anisimov, A.P. Alekseeva, and A.I. Melikhov, Crim. Bul. Baikal State Univ. of Ec. and Law 3, 80-89 (2013)

12. O.A. Kolotkina, I.A. Minnikes, and I.D. Yagofarova, Rus. J. Crim. 12(4), 496-504 (2018)

13. N.I. Kostyuchenko, Bul. Volgograd Acad. Min. of Int. Aff. Rus. 1(48), 182-187 (2019)

14. A.I. Melikhov, A.Yu. Istratenkov, and N.D. Zakharov, Bul. Volgograd Acad. Min. of Int. Aff. Rus. 1(52), 118-124 (2020)

15. A.I. Melikhov, A.N. Gulewski, N.A. Gulewskaya, N.L. Vinogradova, A.V. Zakharov, Private investigation services' development to ensure the world attractiveness of Russian Jurisdiction. Proc. In. Sc. Conf. "Social and Cultural Transformations in the Context of Modern Globalism” (2020) https://doi.org/10.15405/epsbs.2020.10.05.96 